\title{
Preservation of durian timber and coconut timber with soursop leaf extract
}

\author{
Sri Handayani, Endah Kanti Pangestuti and Ninda Adhitya Dharma \\ Departement of Civil Engineering, Universitas Negeri Semarang (UNNES), 50229, Semarang, Indonesia
}

\begin{abstract}
Durian timber and Coconut timber grow a lot in the area of Gunung Pati Semarang, Central Java. The threat of biodeteoration in Indonesia as tropical area is quite high. Therefore, it is necessary to take protection measures in the form of preservation for prevention. The preservatives used in this study are natural preservative of soursop leaf extract. The preservation method used was cold soaking method with variation of concentration of preservative as follows: $0 \%, 5 \%, 10 \%, 15 \%, 20 \%$ and $25 \%$. This study aims to figure out how significant the weight loss of timber and how durian wood and coconut wood's resistance to termites based on the weight loss of timber. Result of examination of termite attack on Coconut timber with preservation of soursop leaf extract $0 \%, 5 \%, 10 \%, 15 \%, 20 \%$ and $25 \%$ obtained by weight loss of wood $17.57 \%, 13.43 \%, 10.61 \%, 7.67 \%, 5.50 \%$ and $4.20 \%$. Meanwhile, the result of examination of termite attack on Durian timber with the concentration of soursop leaf extract $0 \%, 5 \%, 10 \%, 15 \%, 20 \%$ and $25 \%$ showed these following timber weight losses: $18.24 \%, 14.61 \%, 13.04 \%, 11.33 \%, 8.98 \%$ and $7.84 \%$. Based on the wood resistance table, Durian timber with soursop leaf concentration of $20 \%$ and $25 \%$ were classified in the medium classification. Coconut timber with $15 \%$ and $20 \%$ soursop leaf concentrations were classified in the medium classification, while at $25 \%$ concentrations in resistant classification.
\end{abstract}

\section{Introduction}

Good quality timber demand is increasing as the population grows. However, nowadays, it is very difficult to obtain raw materials of a very high quality timber from natural forests. This causes the focus of timber utilization from natural forests to switch to community forests and plantations. Durian and coconut timbers are the commodities which are now starting to be utilized. Durian and coconut timbers grow and they can be found in tropical climates. The timbers that originate from community forests and plantations have different characteristics than the timbers from natural forests [1]. The timbers from contemporary people's forest has not seen its properties especially its durability and durability. Timber from the forest is basically used for various purposes both for carpentry and building materials. However, its use should be supported by technologies that can improve the properties of timber, such as sawmill, drying, pickling, and other processing technology [2]

The durability of timber to the wood decay fungi is also influenced by several factors such as extractive substance in timber, age of the timber, the origin of the timber, the wood decay organism [3].

The threat of biodeteoration in Indonesia is quite high. Therefore, it is necessary to take protection measures in the form of preservation for prevention. Timber from community forest is expected to be a substitute material of timber from natural forests both for the needs of building components and industrial raw materials.
Coconut timber is also known as glugu timber. It is a timber that is obtained from the collection of good coconut trees growing wildly and cultivated as one part of the coconut tree [4]. The average density of Coconut timber is 0.74 then it belongs to the strong class II (specific gravity $0.6-0.9$ ). Coconut timber is included in the durable class III.

Durian timber properties are classified as class II-III with specific gravity of 0.57 . Durian timber belongs to the class of durability IV-V and strong class II-III. Wood is classified as relatively light wood species and has a relatively low durability [5]. Timber preservation with the addition of montan wax and boric acid wax emulsions for $20 \%$ up to $50 \%$ in timber, providing protection from wood-decay fungi [6].

The research had managed to overcome the problem by determine the suitable amount for the Rubber trees. Converting acetic and butyric acids derived from landfill leachate into acetate and butyrate salt, leachate can be fermented and be potentially turned into a valuable timber preservative. The mixture of sodium acetate and sodium butyrate can be a preservative in Rubberwood because it can inhibit the growth of wood decay fungi [7]

Borates prevents fungal decay and are deadly to termites, carpenter ants and roaches - but safe for people and the environment. Boron is not fixed chemically to timber, and it will be leached out if timber is subjected to wet environment [8]. 
The use of bamboo for building materials, especially in the use as a construction, needs a maximum bamboo handling with preservative borax [9]

Termites especially Coptotermes sp. has a wide distribution and has caused severe damage. Various chemicals have been used to cope with the danger of termite attack. However, the use of such chemicals can endanger the environment [10].

Therefore, the chemical materials must be replaced with the use of natural materials for preservatives. From the potential of environmentally friendly soursop leaf extract as an insecticide, it can be used Coptotermes sp as termite controller. Soursop leaves can act as insecticide, larvacide, repellent (insect repellent) and inhibitor. Soursop leaf contains acetogenin compound, such as asimisin, bulatacin and squamosin [11]

The results of the study presented by Grainge and Ahmed (1989) reported that the active ingredients contained by soursop seeds such as alkaloids, annonain, mauricine, and mauricinine may act as antifeedants and insecticides [12]

Soursop leaf extract contains $66 \%$ of monoterpene compounds and $28 \%$ sesquiterpene. In addition, it also contains $11-17 \% \quad \alpha$-pinene, $12.5-24.8 \%$ cymene, and $10.6 \%$ thymyl acetate [13].

Soursop leaf powder can stop the growth of termites and increase termite mortality [14]

The result of this research shows that the flour of soursop leaf from dosage $0,5 \mathrm{gr} / 100 \mathrm{gr}$ grain has an effect on the increasing mortality and decreasing the growth of soy powder beetle (C. analis) on soy grain and can decrease the decay and soy grain weight caused by the attact of soy powder beetle (C. analis) at any deviation. Key words: The flour of sorsop leaf (Annona muricata); the beatle of soy powder (Callosobruchus analis F.) [15].

\section{Materials and Methods}

\subsection{Materials preparation}

The research was conducted at UNNES Civil Engineering Laboratory. This research was an experimental research examining termite attack on Durian timber and Coconut timber. The treatment of this study was the preservation by using natural preservative of soursop leaf extract. The timbers used in this research were Durian timber and Coconut timber obtained in Gunungpati District Semarang.

The 30 pieces on Durian Timber and 30 pieces on Coconut Timber with $25 \mathrm{~mm}$ width, $25 \mathrm{~mm}$ height and $5 \mathrm{~mm}$ thick were used as the test specimens.

Preparation of the test was carried out according to SNI 03-6847-2002 [16] about the Method of Testing the Specific Gravity of Wood and Material of Wood by The Water Immersion and SNI 03-6850-2002 [17] on The Testing Method of Measurement of Wood Water Content and Wood Material

Termite resistance evaluation of the timbers was carried out referring to SNI 01-7207-2006 [18], which included the material preparation, test procedures and statements.

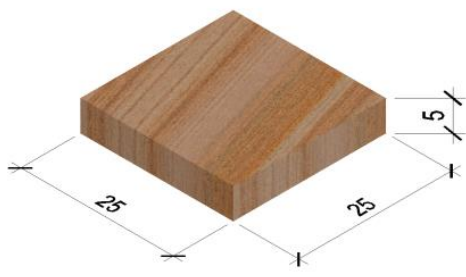

Fig. 1. Size of the specimen

Method of preservation of timber was performed using cold soaking method. The preservatives used in this study were soursop leaf extract with these following variations of concentration: $0 \%, 5 \%, 10 \%, 15 \%, 20 \%$, and $25 \%$. Extraction process was obtained by soaking the soursop leaves that have been cleaned into water inside of containers and was allowed to cool down for 2-3 hours. After the water cooled down, the soursop leaf extract was ready for use as a natural timber preservative. The specimens were soaked with the soursop leaf extract for 7 days.

\subsection{Data Analysis}

The amount of specimen weight loss was calculated using this following equation:

$$
P=\frac{W 1-W 2}{W 2} \times 100 \%
$$

Where,

P : weight Loss (\%)

W1 : Weight of specimen before termited test (g)

W2 : Weight of specimen after termited test (g)

Furthermore, the determination of termite resistance of the timber was based on the classification of timber resistance to termites based on weight loss, as shown in table 1.

Table 1. Classification of Timber Resistance to Termites Based on Weight Loss

\begin{tabular}{|c|c|c|}
\hline Class & Resistance & Weight Loss (\%) \\
\hline I & Very resistant & $<3,52$ \\
\hline II & resistant & $3,25-7,50$ \\
\hline III & Medium resistant & $7,30-10,96$ \\
\hline IV & Bad resistant & $10,96-18,94$ \\
\hline V & $\begin{array}{c}\text { Very bad } \\
\text { resistant }\end{array}$ & $18,94-31,89$ \\
\hline \multicolumn{2}{|c|}{} \\
\hline
\end{tabular}




\section{Results and Discussion}

\subsection{Water Content}

Table 2. Water Content of Durian and Coconut Timber

\begin{tabular}{|c|c|c|}
\multirow{2}{*}{$\begin{array}{c}\text { No of } \\
\text { Test } \\
\text { Specimen }\end{array}$} & \multicolumn{2}{|c|}{ Water content (\%) } \\
\cline { 2 - 3 } & Durian Timber & Coconut Timber \\
\hline 1 & 17.21 & 18.86 \\
\hline 2 & 18.85 & 15.90 \\
\hline 3 & 16.65 & 15.89 \\
\hline 4 & 17.29 & 16.33 \\
\hline 5 & 16.59 & 16.77 \\
\hline Average & 17.32 & 16.62 \\
\hline
\end{tabular}

The water content test results of Durian are presented in Table 1. The average water content of Durian timber is $17.32 \%$. The average water content of Coconut Timber is $16.62 \%$. Water content of Durian Timber was more than that of Coconut Timber

\subsection{Specific Gravity of the Timber}

The specific gravity is the ratio of timber density to the water density at the same volume. The results of the specific gravity of Durian Timber can be seen in Table 3 . The results of this test showed that the average specific gravity of Durian Timber was 0.43. Meanwhile, the average specific gravity of Coconut Timber was 0.53 . Specific gravity of Durian Timber was less than specific gravity of Coconut Timber.

Table 3. The Specific Gravity of Durian and Coconut Timber

\begin{tabular}{|c|c|c|}
\multirow{2}{*}{$\begin{array}{c}\text { Test } \\
\text { Specimen }\end{array}$} & \multicolumn{2}{|c|}{ Specific gravity } \\
\cline { 2 - 3 } & Durian timber & Coconut timber \\
\hline 1 & 0.42 & 0.52 \\
\hline 2 & 0.46 & 0.51 \\
\hline 3 & 0.41 & 0.52 \\
\hline 4 & 0.41 & 0.56 \\
\hline 5 & 0.43 & 0.56 \\
\hline Average & 0.43 & 0.53 \\
\hline
\end{tabular}

The results showed an inverse relationship between timber water content and its specific gravity; higher water content of timber led to the lower specific gravity, or vice versa.

\subsection{The Analysis of Termite Attact Test of DurianTimber}

Table 4. Weight Loss of Durian Timber and Coconut Timber

\begin{tabular}{|c|c|c|c|}
\hline & \multicolumn{2}{|c|}{ Weight Loss (\%) } \\
\hline Code & $\begin{array}{l}\text { Consentration } \\
\text { of Preservative }\end{array}$ & $\begin{array}{l}\text { Durian } \\
\text { Timber }\end{array}$ & $\begin{array}{c}\text { Coconut } \\
\text { Timber }\end{array}$ \\
\hline 1 & $0 \%$ & 18,24 & 17,57 \\
\hline 2 & $5 \%$ & 14,61 & 13,43 \\
\hline 3 & $10 \%$ & 13,04 & 10,61 \\
\hline 4 & $15 \%$ & 11,33 & 7,67 \\
\hline 5 & $20 \%$ & 8,98 & 5,50 \\
\hline 6 & $25 \%$ & 7,84 & 4,20 \\
\hline
\end{tabular}

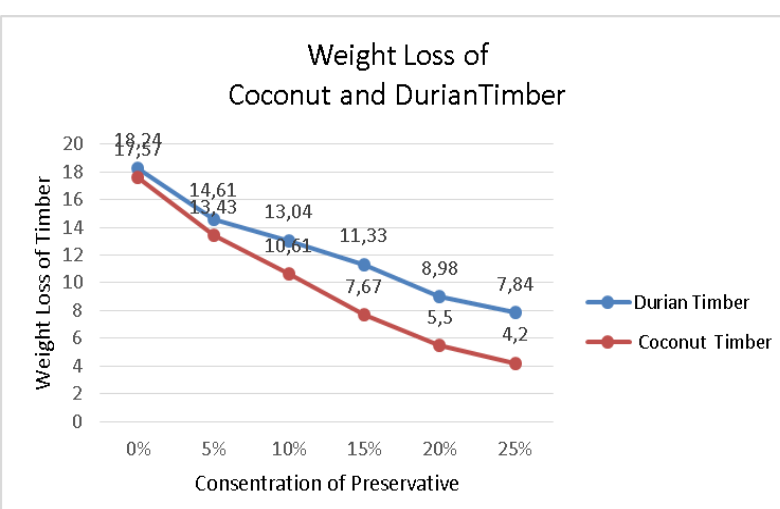

Fig. 2. Weight loss of Durian and Coconut timber

Table 4. shows the average weight loss of timber of Durian timber and Coconut timber based on variation of soursop leaf extract concentration. Test results on Durian timber and Coconut timber showed the tendency of an inverse relationship. The higher content of soursop leaf extract led to the smaller weight loss of timber. This was caused by the higher content of soursop leaf extract into the timber, the cavities in the timber cells became denser because it was filled by the amount of preservative (retention) from soursop leaf extracts. Therefore, the timber cells became denser.

The results of the termite test also showed that the weight loss of Durian timber was higher compared with the weight loss of Coconut timber. This is in accordance with the test results of water content and specific gravity of Durian timber and Coconut timber. The specific gravity of Coconut timber (0.53) was higher than that of Durian timber (0.43). The higher specific gravity led to the lower timber weight loss. On the other hand, the lower specific gravity of timber led to the higher loss weight of timber.

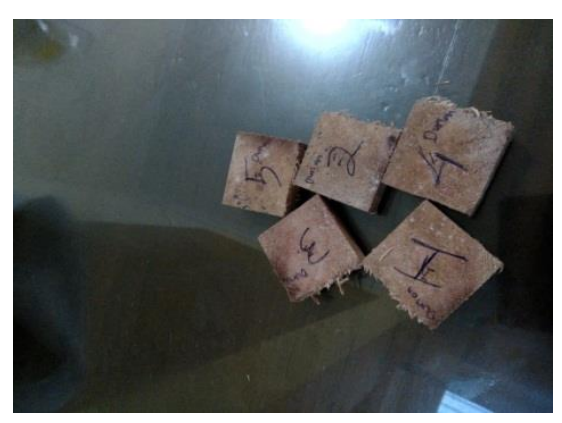

Fig. 3. Test Specimen of Durian timber

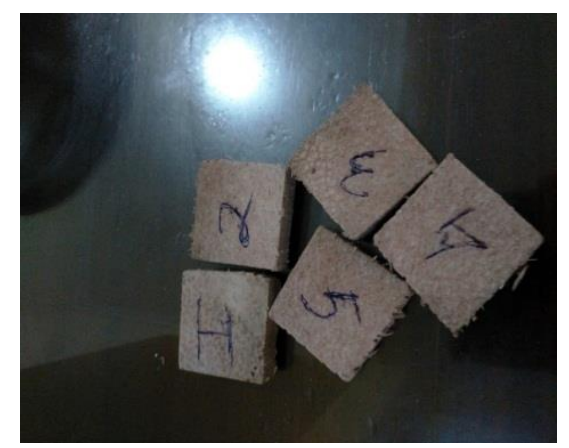

Fig. 4. Test Specimen of Coconut timber 


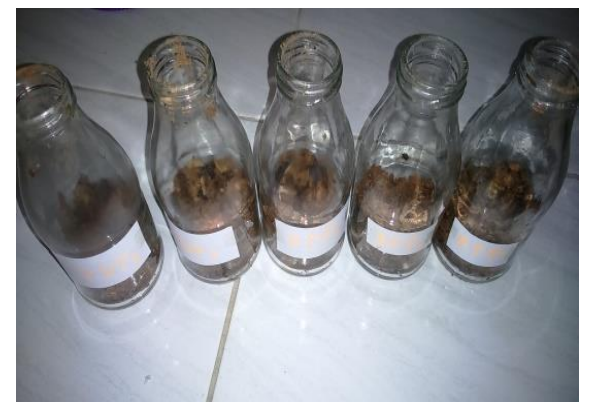

Fig. 5. Termites test

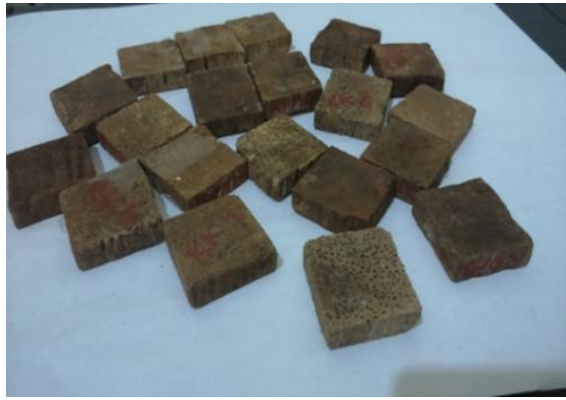

Fig. 6. The specimens after termite test

The result of analysis on timber resistance to termites based on weight loss, showed that the termite attack on coconut timber with soursop leaf extract at $0 \%, 5 \%, 10 \%$, $15 \%, 20 \%$ and $25 \%$ concentrations were presented in table 5 .

Table 5. The Resistance of Durian Timber to Termite attack

\begin{tabular}{|c|c|c|c|c|} 
Code & $\begin{array}{c}\text { Concentration } \\
\text { of } \\
\text { Preservative }\end{array}$ & $\begin{array}{c}\text { Durian } \\
\text { Timber }\end{array}$ & Class & Resistance \\
\hline 1 & $0 \%$ & 18,24 & IV & Bad \\
\hline 2 & $5 \%$ & 14,61 & IV & Bad \\
\hline 3 & $10 \%$ & 13,04 & IV & Bad \\
\hline 4 & $15 \%$ & 11,33 & IV & Bad \\
\hline 5 & $20 \%$ & 8,98 & III & Medium \\
\hline 6 & $25 \%$ & 7,84 & III & Medium \\
\hline
\end{tabular}

Table 6. The Resistance of Durian Timber to Termite attack

\begin{tabular}{|c|c|c|c|c|}
\hline Code & $\begin{array}{c}\text { Concentration } \\
\text { of } \\
\text { Preservative }\end{array}$ & $\begin{array}{c}\text { Coconut } \\
\text { Timber }\end{array}$ & Class & Resistance \\
\hline 1 & $0 \%$ & 17,57 & IV & $\mathrm{Bad}$ \\
\hline 2 & $5 \%$ & 13,43 & IV & $\mathrm{Bad}$ \\
\hline 3 & $10 \%$ & 10,61 & IV & $\mathrm{Bad}$ \\
\hline 4 & $15 \%$ & 7,67 & III & Medium \\
\hline 5 & $20 \%$ & 5,50 & III & Medium \\
\hline 6 & $25 \%$ & 4,20 & III & Resistance \\
\hline
\end{tabular}

Table 5 shows that Durian timber resistance at $0 \%$ $15 \%$ concentration is classified as bad, while $20 \%-25 \%$ is classified as medium. Table 6 shows that Coconut timber resistance at $0 \%-10 \%$ concentration is classified as bad, $15 \%-20 \%$ is classified as medium, while at $25 \%$ concentration is classified as resistant.

Based on the results in tables 5 and 6 , it shows that there is a difference in resistance in Coconut timber and Durian timber for the same concentration. Durian timbers with concentrations of $20 \%$ and $25 \%$ were classified as medium. Meanwhile, Coconut timbers with concentration of $15 \%$ and $20 \%$ were classified as medium and $25 \%$ concentration was classified as resistant. This shows that the termite resistance of Coconut timber is higher than Durian timber.

\section{Conclusions}

Based on the results of research and data analysis on preservation of Durian timber and Coconut timber with soursop leaf extract can be concluded as follows

1. Weight loss of Durian timber is higher compared with weight loss of Coconut timber

2. The termite resistance on Coconut timber with soursop leaf extract $0 \%, 5 \%, 10 \%, 15 \%, 20 \%$ and $25 \%$ showed weight loss of $17.57 \%, 13.43 \%$, $10.61 \%, 7.67 \%, 5.50 \%$ and $4.20 \%$. Meanwhile, the result of examination of termite attack on Durian timber with the concentration of soursop leaf extract $0 \%, 5 \%, 10 \%, 15 \%, 20 \%$ and $25 \%$ showed the result of timber weight loss of $18.24 \%, 14.61 \%, 13.04 \%$, $11.33 \%, 8.98 \%$ and $7.84 \%$

3. The resistance of Coconut timber is higher than Durian timber. Durian timbers with soursop leaf concentration of $20 \%$ and $25 \%$ were classified as medium. Coconut timber with $15 \%$ soursop leaf concentration and $20 \%$ were classified as medium. Meanwhile, the coconut timber at $25 \%$ concentration was classified as resistant.

\section{References}

1. Brazier. Perbedaan sifat kayu hutan alam dan hutan rakyat. Pusat Penelitian dan Pengembangan Hasil Hutan. Bogor (1986) [in Indonesian]

2. Abdurachman, Hadjib N. Pemanfaatan Kayu Hutan Rakyat untuk Komponen Bangunan. www.dephut.go.idfilesKomp_Bangunan.pdf. [3 Agustus 2009]. (2006) [in Indonesian]

3. Martawijaya, A. Keawetan kayu dan factor yang mempengaruhinya. Petunjuk Teknis. Pusat penelitian dan Pengembangan Hasil Hutan dan Sosial Ekonomi Kehutanan, Bogor. (1996). [in Indonesian]

4. Indrosaptono, Djoko. Kayu Kelapa (Glugu) Sebagai Alternatif Bahan Konstruksi Bangunan, dalam Jurnal Arsitektur, Fakultas Teknik, Universitas Diponegoro Semarang, 14 [in Indonesian]

5. Oey Djoen Seng. 1990. Berat Jenis Dari Jenis Jenis Kayu Indonesia dan Pengertian Beratnya Kayu untuk Keperluan Praktek. Nomor 1 Cetakan II. Soewarsono P.H., penerjemah; Bogor : Lembaga Penelitian Hasil Hutan. Terjemahan dari : Specific Gravity of Indonesian Woods and its Significance for Practical Use [in Indonesian] 
6. Lesar, B et al (Montan wax improves performance of boron-based wood preservatives. ELSEVIER. 63, 306-310 (2009) [in Indonesian]

7. Syazwan,Muhammad; Abdulazis, Hamidi; Azan,Huznul; Kwang, Kok. 2017. Preservation Of Rubber Timber Againts Biological Decay By Salt Derived From Leachate. Timber Research 62, 863-872 (2017)

8. Fernando Caldeira. 2010. Boron in Timber Preservation A Riview in Its Physico-Chemical Aspects. Silva Lusitana 18, 179-196 (2010)

9. Handayani Sri. Pengujian Sifat Mekanik Bambu (Metode Pengawetan dengan Boraks). Jurnal JTSP 9, (2007) [in Indonesian]

10. Salmayanti, Pengaruh Konsentrasi dan Lama Perendaman Bahan Pengawet Daun Tembelekan (Lantana camara L.) pada Kayu Bayur (Pterospermum sp) Terhadap Serangan Rayap Tanah (Coptotermes sp). Warta Rimba, 1, 1-8, (2013). [in Indonesian]

11. Tenrirawe, A \& MS, Pabbage, ,Pengendalian Penggerek Batang Jagung (Ostrinia furnacalis G.) Dengan Ekstrak Daun Sirsak (Annona muricata L.),Prosiding Seminar Ilmiah dan Pertemuan Tahunan PEI dan PFI XVIII Komda Sul-Sel,Balai Penelitian Tanaman Sereal, Maros 2007 [in Indonesian]

12. Grainge, M.S. and M.R. Ahmed. Hand Books of Plant with Pest Control Properties. John Wiley and Son. New York (1989)

13. Hadi, M., J.W. Hidayat, K. Baskoro. 2000. Uji Potensi Ekstrak Daun Eupatorium, odoratum sebagai Bahan Insektisida Alternatif: Toksisitas dan Efek Antimakan Terhadap Larva Heliothis armigera Hubner. Jurnal Sains dan Matematika. Fakultas MIPA Undip. Semaran [in Indonesian]

14. Simanjuntak. Efektifitas Tepung Daun Sirsak Untuk Mengendalikan Kumbang Bubuk Kacang Pada Biji Kacang Hijau. Sukorharjo : Fakultas Pertanian Universitas Veteran Bangun Nusantara (2007) [in Indonesian]

15. Yos Wahyu Harinta. Efektifitas Tepung Daun Sirsak (Annona Muricata) Untuk Mengendalikan Kumbang Bubuk Kedelai (Callosobruchus Analis F.) Pada Biji Kedelai (Glycine Max L.). Fakultas Pertanian, Universitas Veteran Bangun Nusantara (2013) [in Indonesian]

16. SNI 03-6847-2002. Metode Pengujian Berat Jenis Kayu dan Bahan Dari Kayu Dengan Cara Pencelupan Dalam Air. PUSLITBANG-Badan Standarisasi Nasional (2002) [in Indonesian]

17. SNI 03-6850-2002. Metode Pengujian Pengukuran Kadar Air Kayu dan Bahan Berkayu. PUSLITBANG-Badan Standarisasi Nasional (2002) [in Indonesian]

18. SNI 01-7207-2006. Uji Ketahanan Kayu dan Produk Kayu Terhadap Organisme Perusak Kayu. PUSLITBANG-Badan Standarisasi Nasional (2002) [in Indonesian]

\begin{tabular}{|l|l|l|}
\hline No & Reviewer & Response \\
\hline 1 & $\begin{array}{l}\text { Author(s) is } \\
\text { required to } \\
\text { have } \\
\text { professional } \\
\text { proofreading } \\
\text { to improve } \\
\text { grammar }\end{array}$ & $\begin{array}{l}\text { Proofreading } \\
\text { process has } \\
\text { been } \\
\text { conducted and } \\
\text { some } \\
\text { sentences have } \\
\text { been revised }\end{array}$ \\
\hline 2 & $\begin{array}{l}\text { Unclear } \\
\text { sentences are } \\
\text { found in this } \\
\text { paper3 }\end{array}$ & $\begin{array}{l}\text { Unclear } \\
\text { sentences have } \\
\text { been revised } \\
\text { and modified }\end{array}$ \\
\hline 3 & $\begin{array}{l}\text { Author(s) did } \\
\text { not write } \\
\text { clearly about } \\
\text { "time" } \\
\text { "duration" }\end{array}$ & $\begin{array}{l}\text { After the water } \\
\text { cooled down, } \\
\text { the soursop } \\
\text { leaf extract } \\
\text { was ready for } \\
\text { use as a natural } \\
\text { timber } \\
\text { preservative. } \\
\text { The specimens } \\
\text { were soaked } \\
\text { with the } \\
\text { soursop leaf } \\
\text { extract for 7 } \\
\text { days. }\end{array}$ \\
\hline
\end{tabular}

